\title{
Deficiency of Glucose-6-Phosphate Dehydrogenase found in a Case of Hepatic Fructose-1,6- Diphosphatase Deficiency
}

\author{
AKIHIKO KINUGASA, TOMOICHI KUSUNOKI, AND AKIO IWASHIMA \\ Department of Pediatrics, Kyoto Prefectural University of Medicine, (A. K., T. K.) Department of Biochemistry, Kyoto \\ Prefectural University of Medicine, (A. I.) Kyoto, Japan
}

\begin{abstract}
Summary
The first case of fructose-1,6-diphosphatase (FDPase) deficiency in Japan showed a decreased activity of glucose-6-phosphate dehydrogenase (G6PD) in the liver, white, and red blood cells. In the enzymatic study of G6PD which was partially purified from red cells, the following characteristics were observed in the enzyme of the patient. 1) The G6PD activity of the patient was reduced to $17 \%$ of normal, but no evidence of a hemolytic episode was found in his past and family history. 2) In the investigation of G6PD of the patient, no abnormalities were observed in its enzymatic parameters such as electrophoretic mobility, Km for G6P and NADP, Ki for NADPH, the utilization of 2-deoxy G6P and deamino NADP, heat-stability, and pH curves. 3) The dissociation constants of red blood cell G6PD for NADP and NADPH, which were obtained from the investigations on the reactivation of coldinactivated G6PD at $37^{\circ} \mathrm{C}$, were about 3 times higher in the patient as compared to the values of the normal controls.

Based on these findings, it might be concluded that the G6PD deficiency found in the red blood cells of this case of a FDPase deficiency is a unique variant, which could not be characterized by using only the method recommended by a World Health Organization (WHO) scientific group. Considering that the abnormality observed in the G6PD of this patient was a decrease in the affinity of the enzyme for its coenzymes, the dissociation constants for the coenzymes in reactivation process might be another important kinetic parameter in characterizing the G6PD deficiency.
\end{abstract}

\section{Speculation}

The red cell G6PD of a case of FDPase deficiency showed a decreased enzymatic activity and a lowered affinity for its coenzymes in reactivation process. Although it is itrongly suggested that these two rare enzyme deficiencies take place in an individual coincidentally, a possible relationship of the two enzyme deficiencies should be considered. Further studies on these enzyme deficiencies now appear necessary to learn more about this association.

Hepatic FDPase is one of the four rate-limiting enzymes in hepatic gluconeogenesis. Some 10 cases of children's hepatic FDPase deficiency with hypoglycemia, metabolic acidosis, and hepatomegaly have been described from the time that Baker and Winegrad reported the first case in 1970 (2). Recently, the first case of this disorder was reported in Japan (6). In this case, we also found a deficiency of G6PD in the liver, white, and red blood cells, which had not been reported in any other case of this disorder. The frequency of G6PD deficiency in Japan has been reported to be extraordinarily low, less than $0.1 \%$ (11). Therefore, it is of interest to note that this patient has two very rare diseases, a FDPase deficiency and a G6PD deficiency. In order to clarify the character of the G6PD deficiency associated with the FDPase deficiency, the G6PD was studied enzymatically and electrophoretically, which was partially purified from red blood cells of the patient and normal subjects.

\section{CASE REPORT}

The patient was a 3-yr-old boy, slightly obese, but physically and mentally normal for his age, who had been noted to have frequent episodes of symptomatic hypoglycemia and hepatomegaly from 8 months of age. In his past history, there is no evidence suggesting the presence of a hemolytic anemia and the jaundice in his neonatal period showed a normal course. His family history is noteworthy in that one of his two sisters died of hypoglycemia and hepatomegaly at 14 months of age. His parents, not consanguineous, were in good health.

The metabolic state of the patient was studied by loading tests of gluconeogenic substrates. After an oral administration of glycerol $(0.5 \mathrm{~g} / \mathrm{kg}$ of body weight) or fructose $(1 \mathrm{~g} / \mathrm{kg}$ of body weight), striking hypoglycemia was provoked within $30 \mathrm{~min}$, with a concomitant fall of inorganic phosphate and rise of uric acid in the serum. Alanine $(0.5 \mathrm{~g} / \mathrm{kg}$ of body weight, per os) did not cause any significant change in blood glucose level. The result of a ketogenic provocative test satisfied the criteria of "ketotic hypoglycemia" with the exception that there was no acetonuria. In addition to the marked hepatomegaly, the presence of reducing substances in urine and a striking elevation of the plasma levels of lactate, pyruvate, alanine, and the ratio of lactate/pyruvate during episodes of hypoglycemia were noticed.

The liver biopsy revealed a mild to moderate fatty infiltration and an increase in glycogen of hepatic cells. Presumably, the lipid storage might account for the soft aind nontender hepatomegaly which fluctuated in size with episodes of hypoglycemia. The markedly reduced activity of FDPase in the biopsy specimen gave us the final diagnosis of this case as a FDPase deficiency (Table 1). But the activities of other hepatic enzymes, glucose-6-phosphatase, pyruvate carboxylase, phosphoenolpyruvate carboxykinase, FDP aldolase and F-1-P aldolase were all within normal ranges. It was found, however, that G6PD activity was markedly reduced in liver, white, and red blood cells of the patient (Table 1). The activity of leukocyte FDPase in all of the family members was then determined. It was significantly low in the patient and 50\% of normal in his mother. His father and a healthy sister showed normal leukocyte FDPase activity. Consequently, the mother seems to be a heterozygote, however, the mode of inheritance remains to be clarified.

He was discharged from the hospital and put on a regimen of frequent food intake high in carbohydrates, excluding sucrose as much as possible. From that time, a decreased frequency of episodes of his symptomatic hypoglycemia was noticed. A large dose of folic acid ( $30 \mathrm{mg}$ daily for 6 months) was not effective on this patient, contrary to the promising result reported previously by Greene et al. (4). On a recent routine hospital evaluation at age 
Table 1. Enzyme activities of FDPase, G6PD, and 6-phosphogluconate dehydrogenase in liver, white, and red blood cells of the patient, controls, and family of the patient ${ }^{1}$

\begin{tabular}{|c|c|c|c|c|c|}
\hline & \multirow{2}{*}{ Patient } & Controls & \multicolumn{3}{|c|}{ Family } \\
\hline & & male, $5 \mathrm{Y}$; male, $2 \mathrm{M}$ & Father & Mother & Sister \\
\hline \multicolumn{6}{|l|}{$\overline{\text { Liver (supernatant) }}$} \\
\hline FDPase (pH 7.5) & $0.0-0.7$ & 52.3 & & & \\
\hline$(\mathrm{pH} 9.4)$ & 0.0 & 25.8 & & & \\
\hline G6PD & 4.9 & 15.0 & & & \\
\hline 6-phosphogluconate dehydrogenase & 23.0 & 25.2 & & & \\
\hline \multicolumn{6}{|l|}{ White blood cells } \\
\hline FDPase (pH 7.0) & 0.32 & $1.67 \pm 0.27(8)^{2}$ & 1.35 & 0.70 & 2.31 \\
\hline G6PD & 122 & $201 \pm 26(6)^{2}$ & 230 & 178 & 260 \\
\hline 6-phosphogluconate dehydrogenase & 78 & $87 \pm 11(6)^{2}$ & & 86.5 & \\
\hline \multicolumn{6}{|l|}{ Red blood cells } \\
\hline FDPase & N.D..$^{3}$ & N.D. ${ }^{3}$ & N.D. ${ }^{3}$ & N.D. ${ }^{3}$ & N.D. ${ }^{3}$ \\
\hline G6PD & 1.50 & $6.08 \pm 0.35(5)^{2}$ & 6.02 & 5.14 & 7.10 \\
\hline 6-phosphogluconate dehydrogenase & 5.41 & $5.37 \pm 0.23(5)^{2}$ & & 4.28 & 4.84 \\
\hline
\end{tabular}

1 The activities of FDPase were measured by the method of Baker and Winegrad (2) and expressed as $\mu$ moles of NADPH formed $/ \mathrm{min} / \mathrm{g}$ of protein The activities of G6PD and 6-phosphogluconate dehydrogenase were measured by the method of Glock and MacLean (5) and expressed as $\mu$ moles of $\mathrm{NADPH}$ formed $/ \mathrm{min} / \mathrm{g}$ of protein for those of liver and white blood cells and $\mu \mathrm{moles}$ of NADPH formed $/ \mathrm{min} / \mathrm{g}$ of hemoglobin for that of red blood cells.

${ }^{2}$ Mean \pm 1 SD (No. of normal subjects).

${ }^{3}$ N.D. $=$ Not detectable.

Table 2. Enzymatic characteristics of G6PD of the patient and a control

\begin{tabular}{|c|c|c|c|c|c|c|c|c|c|}
\hline & \multirow[b]{2}{*}{$\begin{array}{l}\text { RBC en- } \\
\text { zyme ac- } \\
\text { tivity } \\
(\%)\end{array}$} & \multirow[b]{2}{*}{$\begin{array}{c}\text { Electrophoretic } \\
\text { mobility } \\
(\%)\end{array}$} & \multirow[b]{2}{*}{$\begin{array}{c}\mathrm{Km} \text { G6P } \\
(\mu \mathrm{M})\end{array}$} & \multirow[b]{2}{*}{$\begin{array}{c}\text { Km NADP } \\
(\mu \mathrm{M})\end{array}$} & \multirow[b]{2}{*}{$\begin{array}{c}\text { Ki NADPH } \\
(\mu \mathrm{M})\end{array}$} & \multicolumn{2}{|c|}{ Utilization } & \multirow[b]{2}{*}{$\begin{array}{c}\text { Heat } \\
\text { stability } \\
\left(50^{\circ} \mathrm{C}\right)\end{array}$} & \multirow[b]{2}{*}{$\begin{array}{c}\mathrm{pH} \text { curve } \\
\text { (pH optimal) }\end{array}$} \\
\hline & & & & & & $\begin{array}{c}\text { 2-deoxy } \\
\text { G6P } \\
\text { (\% of } \\
\text { G6P) } \\
\end{array}$ & $\begin{array}{l}\text { deamino } \\
\text { NADP } \\
\text { (\% of } \\
\text { NADP) } \\
\end{array}$ & & \\
\hline$\overline{\text { Patient }}$ & 17 & 100 (tris, ph) $^{1}$ & 46 & 5.1 & 26.2 & 4.8 & 44 & Normal & Normal $(8.0-9.0)$ \\
\hline Control & 100 & 100 (tris, ph) $^{1}$ & 49 & 6.5 & 22.5 & 4.4 & 57 & Normal & Normal (8.0-9.0) \\
\hline Normal $B^{2}$ & & & $37-71$ & $2.6-6.6$ & $17-31$ & $1.6-6.4$ & $51-69$ & & Normal (8.0-9.0) \\
\hline
\end{tabular}

${ }^{1}$ Tris = tris- $\mathrm{HCl}$ buffer $(\mathrm{pH} \mathrm{8.8)}, \mathrm{ph}=$ phosphate buffer $(\mathrm{pH} 7.0)$.

${ }^{2}$ Normal B: reported by Nakashima et al. (11).

6 , he was about 50 percentile for both height and weight. The physical examination showed that he was completely normal and his liver was no longer palpable. Neurologic and mental examinations were within normal limits, and he is doing well in a primary school.

\section{MATERIALS AND METHODS}

For each investigation, about $10 \mathrm{ml}$ of heparinized venous blood was drawn from the patient and normal controls after obtaining consents. After removing the buffy coat by a centrifugation ( 3000 $X \mathrm{~g}, 5 \mathrm{~min}$ ), the red blood cells were washed three times with normal saline containing $1 \mathrm{mM}$ EDTA. The partial purification of red cell G6PD and its characterization were performed by the standard method recommended by the WHO scientific group (13) with the only exception of electrophoresis. The electrophoresis was conducted using a phosphate buffer system ( $\mathrm{pH} 7.0)$ and a tris- $\mathrm{HCl}$ buffer system ( $\mathrm{pH} 8.8$ ) on Cellogel purchased from Chemetron (Milano, Italy). NADP-free G6PD was prepared by removing NADP in each step of the standard method of the WHO scientific group and then by dialyzing the partially purified enzyme against the NADP-free $0.05 \mathrm{M}$ tris- $\mathrm{HCl}$ buffer $(\mathrm{pH} 8.0$ ) containing $1 \mathrm{mM}$ EDTA and $1 \mathrm{mM} 2$-mercaptoethanol at $4^{\circ} \mathrm{C}$ for $24 \mathrm{hr}$. Cold-inactivated G6PD was obtained by storing the NADPfree enzyme at below $4^{\circ} \mathrm{C}$ for more than $48 \mathrm{hr}$. The activity of the cold-inactivated G6PD was usually less than $10 \%$ of the original activity of the enzyme which was partially purified in the presence of NADP under the standard condition.
Reactivation of the cold-inactivated G6PD was carried out by incubating the enzyme with $0.05 \mathrm{M}$ tris- $\mathrm{HCl}$ buffer ( $\mathrm{pH} 8.0$ ) containing $1 \mathrm{mM}$ EDTA, $1 \mathrm{mM}$ 2-mercaptoethanol and, of NADP or NADPH at $37^{\circ} \mathrm{C}$ for $3 \mathrm{hr}$. In the reactivation, the enzyme solution was diluted to $0.5 \mathrm{mg}$ protein per $\mathrm{ml}$ with the above buffer. The maximum reactivation was achieved by 180 -min incubation.

Purification of G6PD by an affinity chromatography was performed using 2',5'-ADP Sepharose 4B which was purchased from Farmacia Fine Chemicals (Uppsala, Sweden) (3). Polyacrylamide gel disc electrophoresis was carried out by the method of Bakay and Nyhan (1) and SDS-polyacrylamide gel disc electrophoresis was conducted on $10 \%$ gel based on the method of Weber and Osborn (12).

\section{RESULTS}

The electrophoretic and kinetic characteristics of red blood cell G6PD of the patient and a normal control are listed in Table 2. The G6PD activity of the patient was reduced to $17 \%$ of normal, however, no abnormalities were observed in its enzymatic parameters such as electrophoretic mobility, $\mathrm{Km}$ for G6P and NADP, $\mathrm{Ki}$ for NADPH, utilization of 2-deoxy G6P and deamino NADP, heat-stability, and $\mathrm{pH}$ curves. These results suggest that G6PD of this patient might be one of variants which could not be characterized by the standard method recommended by the WHO scientific group.

As shown in Table 3, the specific activity of red cell G6PD of 
the patient and a control increased stepwise by the two successive column chromatography using DEAE cellulose and $2^{\prime}, 5^{\prime}-\mathrm{ADP}$ Sepharose 4B, respectively. Because the rate of increase in the specific activity of the patient's enzyme was identical to that of the normal control, it was strongly suspected that the G6PD of the patient might have some qualitative abnormalities in its molecule. However, the present purification was not enough to confirm the above conclusion, because SDS-polyacrylamide gel disc electrophoresis of the elute of the column chromatography on 2',5'-ADP Sepharose 4B showed the contamination with substantial amounts of another protein, showing a faster electrophoretic mobility than that of monomeric G6PD (data are not shown). Because the patient was a 5-yr-old boy, the starting volume of blood available for the present purification was limited to about $10 \mathrm{ml}$, therefore, the further purification of the enzyme was impossible.

The cold-inactivated G6PD could be reactivated in the presence of NADP or NADPH at $37^{\circ} \mathrm{C}$ and the restoration of the enzyme activity was dependent on the concentration of NADP or NADPH in the incubation mixtures. It is of interest to note that G6PD of the patient required about 10 times higher concentration of NADP or NADPH than that of normal for a complete restoration. From the double-reciprocal plots inserted in Figure 1, the following parameters concerning reactivation of the cold-inactivated G6PD were obtained, which might be considered to be dissociation constants, $\mathrm{Kd}$ values of $\mathrm{G} 6 \mathrm{PD}$ for its coenzymes at $37^{\circ} \mathrm{C}$. The $\mathrm{Kd}$

Table 3. Change in specific activity of red cell G6PD by purification

\begin{tabular}{lccc}
\hline Step of purification & \multicolumn{2}{c}{$\begin{array}{c}\text { Specific activity } \\
\text { (IU/g protein) }\end{array}$} & $\begin{array}{c}\text { Ratio of } \\
\text { specific } \\
\text { activity }\end{array}$ \\
\cline { 2 - 4 } & Patient & Control & $\begin{array}{c}\text { Patient/ } \\
\text { control) }\end{array}$ \\
\hline Hemolysate & $0.5^{2}$ & $3.0^{2}$ & $1 / 6$ \\
DEAE cellulose & 17.5 & 128.7 & $1 / 7$ \\
2',5'-ADP Sepharose 4B $^{\prime}$ & 1580 & 10700 & $1 / 7$ \\
\hline
\end{tabular}

$1,1 \mathrm{IU}=1 \mu \mathrm{mole}$ of NADPH formed $/ \mathrm{min}$.

${ }^{2}$ The protein in hemolysates was measured by assuming a protein concentration of $35 \mathrm{~g} / 100 \mathrm{ml}$ of cells.
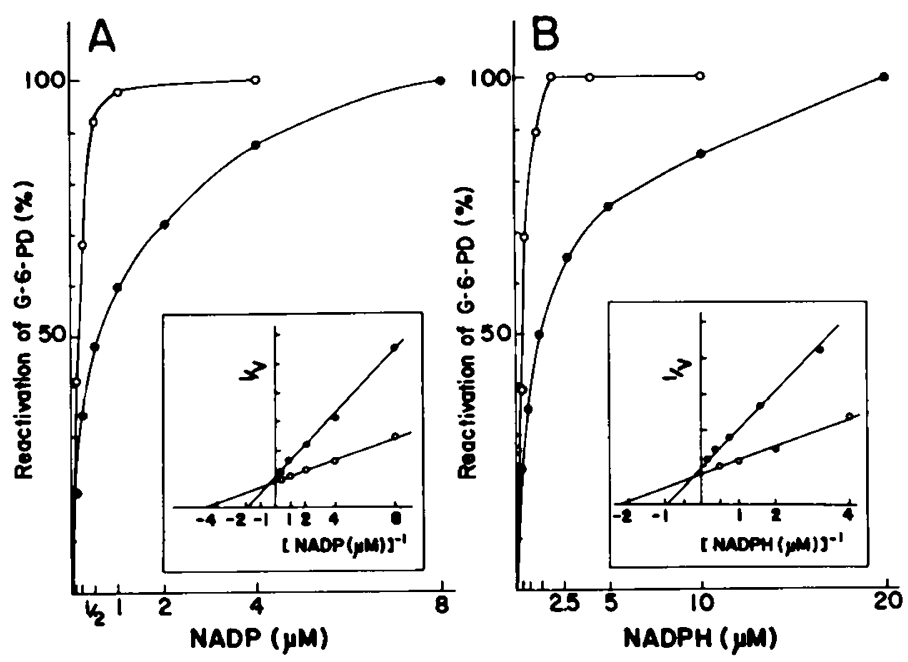

Fig. 1. Effect of NADP $(A)$ and NADPH $(B)$ on the reactivation of the cold-inactivated G6PD partially purified from red blood cells of a normal subject $(\mathrm{O}-\mathrm{O})$ and the patient $\left(\mathrm{O}^{-}\right)$. The inserts show the doublereciprocal plots. The reactivation was carried out at $37^{\circ} \mathrm{C}$ for $180 \mathrm{~min}$ in the incubation mixtures containing $0.05 \mathrm{M}$ tris- $\mathrm{HCl}$ buffer $(\mathrm{pH} 8.0), 1 \mathrm{mM}$ EDTA and $1 \mathrm{mM} 2$-mercaptoethanol with varying concentrations of NADP or NADPH.
Table 4. Dissociation constants of G6PD for its coenzymes at

\begin{tabular}{lcc}
\multicolumn{3}{c}{$37^{\circ} \mathrm{C}$} \\
\hline & $\begin{array}{c}\mathrm{Kd} \text { for NADP } \\
(\mu \mathrm{M})\end{array}$ & $\begin{array}{c}\text { Kd for NADPH } \\
(\mu \mathrm{M})\end{array}$ \\
\hline Controls $(n=5)$ & $0.18 \pm 0.02^{\prime}$ & $0.49 \pm 0.03^{\prime}$ \\
Patient & 0.68 & 1.22 \\
\hline
\end{tabular}

'Mean \pm 1 SD.

value of G6PD for NADP and NADPH of the patient are 0.68 and $1.22 \mu \mathrm{M}$, respectively, whereas those of normal subjects are 0.18 and $0.49 \mu \mathrm{M}$, respectively. Thus, it is clear that patient's G6PD has three times higher Kd values as compared with that of normal (Table 4).

Between the patient and normal controls, no differences could be found in characteristics of the three bands of G6PD which were obtained by the enzyme-stain after an electrophoresis on polyacrylamide gel and in the interconvertible changes in the three bands which were induced by a preincubation of the coldinactivated enzyme with $20 \mu \mathrm{M}$ NADP or NADPH at $37^{\circ} \mathrm{C}$ (data are not shown).

\section{DISCUSSION}

This case of FDPase deficiency was proved to have a combined deficiency of G6PD. G6PD deficiency appears to be rare in Japan and only five reports on G6PD variants have been issued (7-11). The present study was undertaken in an attempt to elucidate the character of the patient's G6PD and to decide if the G6PD deficiency is caused secondarily by the FDPase deficiency or it simply represents a part of the double enzymatic defects, the coincidental association of the two rare enzyme deficiencies.

Although the G6PD of the patient may belong to the class 3 by Yoshida and Beutler (15) according to the standard method recommended by the WHO scientific group, the present results suggest that this patient's G6PD might be a unique variant as described in the following. G6PD of this case showed a reduced affinity for its coenzymes (Fig. 1). Yoshida (14) described that the dissociation constant of the G6PD-NADP complex is $1.7 \times 10^{-7}$ $M$ and that of the G6PD-NADPH complex is $4.9 \times 10^{-7} \mathrm{M}$ at $37^{\circ} \mathrm{C}$. These values are quite the same as those obtained from the present study on reactivation of the cold-inactivated G6PD of normal subjects at $37^{\circ} \mathrm{C}($ Table $4, \mathrm{Kd}$ for $\mathrm{NADP}=1.8 \pm 0.2 \times$ $10^{-7} \mathrm{M}$ and $\mathrm{Kd}$ for NADPH $=4.9 \pm 0.3 \times 10^{-7} \mathrm{M}$ ). Therefore, these parameters seem to represent the dissociation constant of G6PD for its coenzymes. As the Kd values of the patient's G6PD are about three times higher than those of normal controls (Table 4 ), it is strongly suggested that G6PD deficiency of this case may be caused by some qualitative changes in its molecule, despite the standard method failed to characterize G6PD of this patient. Furthermore, the presence of qualitative changes in the G6PD of the patient was suspected by the purification of the enzyme, although not complete, showing that the ratio of the specific activity of the enzyme between the patient and a normal control did not change during the two purification procedures (Table 3 ). Thus, it might be concluded that the G6PD deficiency found in the red blood cells of this case of FDPase deficiency is a unique variant, which could not be characterized by using only the standard method recommended by the WHO scientific group. Considering that the abnormality observed in G6PD of this case was a decrease in the affinity of the enzyme for its coenzymes, the dissociation constants for the coenzymes in the reactivation process might be another important parameter in characterizing the G6PD deficiency.

Finally, although it is strongly suggested that the G6PD deficiency found in this case is due to the qualitative abnormality in the enzyme molecule, not secondarily to the FDPase deficiency, the question about the association of the two rare hereditary disorders of carbohydrate metabolism, a FDPase deficiency and 
a G6PD deficiency, which are known to be transmitted as an autosomal recessive and an $\mathrm{X}$-linked recessive trait, respectively, has not been answered.

Because of a lack of the evidence of hemolytic anemia, the G6PD deficiency of this case might belong to the variants in class 3 (moderate to mild enzyme deficiency without hemolytic anemia) of the classification proposed by Yoshida and Beutler (15). The normal $\mathrm{K} . \mathrm{m}$ values for G6P and NADP, the normal $\mathrm{Ki}$ value for NADPH and the partial deficiency of the enzyme activity $(17 \%$ of normal) may favor the catalytic activity of this variant enzyme in the red blood cells under a physiologic condition (14).

\section{REFERENCES AND NOTES}

1. Bakay, B., and Nyhan. W. L.: An improved technique for the separation of glucose-6-phosphate dehydrogenase isoenzymes by disc electrophoresis on polyacrylamide gel. Biochem. Genet., 3: 571 (1969).

2. Baker. L., and Winegrad. A. I.: Fasting hypoglycemia and metabolic acidosis associated with deficiency of hepatic fructose-1.6-diphosphatase activity. Lancet. 2: 13 (1970).

3. De Flora. A., Morelli. A., Benatti, U.. and Giuliano. F.: An improved procedure for rapid isolation of glucose-6-phosphate dehydrogenase from human erythrocytes. Arch. Biochem. Biophys., 169: 362 (1975).

4. Greene, H. L., Stifel, F. B.. and Herman, R. H.: "Ketotic hypoglycemia" due to hepatic fructose-1,6-diphosphatase deficiency: treatment with folic acid. Am. J. Dis. Child., 124: 415 (1972).

5. Glock. G. E., and MacLean. P.: Further studies on the properties and assay of glucose-6-phosphate dehydrogenase and 6-phosphogluconate dehydrogenase of rat liver. Biochem. J.. 55: 400 (1963).

Copyright (C) 1979 International Pediatric Research Foundation, Inc. $0031-3998 / 79 / 1312-1361 \$ 02.00 / 0$
6. Kinugasa, A., Tozawa, M., Nakata, K., Ohya, N., Sawada, T., and Kusunoki, T.: The first case of fructose-1,6-diphosphatase deficiency in Japan. Acta Paediatr. Jap.. 80: 326 (1976).

7. Kojima, H.: Congenital nonspherocytic hemolytic disease (CNHD) due to a G6PD variant: G6PD Kyoto. Acta Haematol. Jap., 35: 32 (1972).

8. Miwa, S., Nakashima, K., Ono, J., Fujii, H., and Suzuki, E.: Three glucose 6phosphate dehydrogenase variants found in Japan. Hum. Genet., 36: 327 (1977).

9. Miwa, S., Ono, J., Nakashima, K., Abe, S., Kageoka. T., Shinohara, K., Isobe, J., and Yamaguchi. H.: Two new glucose 6-phosphate dehydrogenase variants associated with congenital nonsherocytic hemolytic anemia found in Japan: Gd(-) Tokushima and Gd(-) Tokyo. Am. J. Hematol.. 1: 433 (1976).

10. Nakai, T., and Yoshida, A.: G6PD Heian, a glucose-6-phosphate dehydrogenase variant associated with hemolytic anemia found in Japan. Clin. Chim. Acta. 51: 199 (1974).

11. Nakashima, K., Ono. J., Abe, S.. Miwa, S., and Yoshida, A.: G6PD Ube, a glucose-6-phosphate dehydrogenase variant found in four unrelated Japanese families. Am. J. Human Genet.. 29: 24 (1977).

12. Weber, K., and Osborn. M.: The reliability of molecular weight determination by dodecyl sulfate-polyacrylamide gel electrophoresis. J. Biol. Chem., 244: 4406 (1969).

13. WHO Scientific Group: Standardization of procedures for the study of glucose6-phosphate dehydrogenase. WHO Tech. Rep. Ser., No. 366 (1967).

14. Yoshida, A.: Hemolytic anemia and G6PD deficiency. Science. 179: 532 (1973).

15. Yoshida, A., and Beutler, E.: Human glucose-6-phosphate dehydrogenase variants: a supplementary tabulation. Ann. Hum. Genet.. 41: 347 (1978).

16. Requests for reprints should be addressed to: Akihiko Kinugasa, M. D.. Department of Pediatrics. Kyoto Prefectural University of Medicine, Nishijin, Kyoto, (602). Japan.

17. Received for publication October 17, 1978.

18. Accepted for publication January 9, 1979. 